\title{
AN ANALYSIS OF ERRORS ON THE USING SIMPLE PAST IN WRITING A NARRATIVE TEXT
}

\author{
Umar \\ English Department of STKIP Paracendekia NW Sumbawa \\ Email: umarstkip@gmail.com
}

\begin{abstract}
This study aimed to examine errors on past tense in a writing a narrative text of by 12 participants. The participants were second semester students of English Education Department of STKIP Paracendekia NW Sumbawa in the academic year 2014/2015. This research was a descriptive qualitative research. The instrument used for this study was participants' written narrative texts. The results of the study show that there were errors committed by the participants on using past tense. All of the errors on using past tense in the written narrative texts was identified and classified; these were addition, omission, and misformation. These aspects of writing in English pose the most difficult problems to participants. This study has shed light on the manner in which students internalize the rules of the target language, which is English. Such an insight into language learning problems is useful to lecturers because it provides information on common trouble-spots in language learning which can be used in the preparation of effective teaching materials.
\end{abstract}

Keywords: Error analysis, past tense, writing narrative text

\section{INTRODUCTION}

Today we face many problems of life, and in this global era we are supposed to have a lot of skills to made ourselves surviving in each part of life needs. In the global era English is important because English is used to communicate all people in the world. English plays important roles bearing on many aspects, including economics, education, military and politics.

Nowadays we cannot avoid the interaction with other nation in the world. because we need to master a language that is widely used all over the world. Harmer (2001: 2) predicted that English would remain dominant among world languages and remain a vital linguistic tool for many business people, academicians, tourists and citizens of the world wish to communicate easily across nationalities.

English is the first foreign language in Indonesia, which is taught from elementary level to university level. English is also intensively used in international communication either in written or in spoken communication. In addition, many books of science, technology, art and other published issues are written in English.

In learning English there are four skills that should be mastered by the students, those are listening, reading, speaking, and writing. These four skills are often regarded as serious problems by them. They commonly feel anxious when they are assigned to do the task, especially when they are asked to understand an English text.

Among the four skills, based on the researcher experience, writing is considered as the most difficult one to learn by students. This is because it involves several components which have to be considered in writing, namely: content, rhetoric vocabulary grammatical structures and writing mechanics such as punctuation and capitalization.

According to Langan (2011), writing is actually a skill which grows as a result of constant practices. From this perspective, writing implies the successful transmission of ideas from a speaker to a listener via a text, and this exchange of information becomes a powerful means to motivate and encourage the development of language skills. In writing skill of English, the past tense pattern is very important to study. For example, the students want to write their experience about vacation in a place it will be easy for them because all the past event will be used in the writing task.

In English, there are integrated skills to master such as: speaking, listening, reading, and writing and three components of language learning that should be mastered by the students, that is; vocabulary, pronunciation and 
grammar. Learners are supposed to master grammar because it provides a set of rules that enable them to produce correct sentences. Grammar occupies a central position in the study of language because grammar is essential for the learners to identify the punctuation and help in understanding literary and non-literary texts. Nowadays, grammar has been taught in all Indonesian educational institutions. However, the students face many difficulties in mastering grammar since they have to master many rules in producing sentences in English, for example, tenses in English and other grammatical forms.

The underlying assumption is that students' errors made in grammar are systematic and classifiable. Attention to error type and an understanding of the violation or misuse of specific grammar rules offers teachers a means of helping students deal with language and usage problems. Errors can be used as the feedback because knowing the learners' errors, the teachers can realize whether their materials and their techniques are effective or not. Furthermore Brown (2001:165) states that error refers to those idiosyncrasies of system within which a learner is operating at the time. Therefore, this study can be used as a feedback for the teachers and the learners themselves in learning simple past tense as one of tenses form in English.

\section{Statement of the Problem}

Based on the background above, the statement of the problems as follows:

1) What kinds of errors are committed by the second semester students of English Education Department of STKIP Paracendekia NW Sumbawa on the using simple past tense in writing a narrative text?

2) What are the causes of the errors on the using simple past tense in writing a narrative text of the second semester students of English Education Department of STKIP Paracendekia NW Sumbawa?

\section{Objectives oftheStudy}

Based on the statement of problems above, the objectives of the study formulates as follows:

1) to find out kinds of errors on the using simple past tense in a writing narrative text made by the second semester students of English Education Department of STKIP Paracendekia NW Sumbawa.

2) to find out the causes of errors on the using simple past tense in writing a narrative text for the second semester students of English
Education Department of STKIP Paracendekia NW Sumbawa.

\section{REVIEWE OF RELATED LITERATURE \\ A. Error \\ 1. Concept of errors}

There are some definitions of errors. Errors in a language learning process can be defined as "systematic deviations due the learner's still developing knowledge of the school language rule system. According to Corder (1974), error analysis has two objects: one theoretical and another applied. The theoretical object serves to "elucidate what and how a learner learns when he studies a second language." And the applied object serves to enable the learner "to learn more efficiently by exploiting our knowledge of his dialect for pedagogical purposes."

The concept of errors in this study is the errors in language learning such as what is learned and how does learning take place. The first question concerns with product and the second concerns with the process of language learning. They have relationship because the answer to the second questions is strongly dependent on how the first question is answered, since what take place in the learners head is not open to direct observation.

\section{a. Notions of Errors}

According to Richard and Corder (1974:66-67) that the sources of error are divided into three types: inter-lingual, intralingual or developmental error, and context of learning. Each type of the above errors covers some crucial different concepts. According to Richards (1992) they are "items produced by the learner which reflect not the structure of the mother tongue, but generalizations based on partial exposure to the target language. So, in this case, the learners tries to derive the rules behind the data to which he/she has been exposed, and may develop hypotheses that correspond neither to the mother tongue nor to the target language.

\section{b. Difference between Error and Mistake}

Many people think that between error and mistake are the same. Yet both of them are different. Human learning, including second language learning is fundamentally the process of involving the making of mistakes. When the learners are involved in the process of learning, s/he cannot absolutely avoid making mistakes.

According to Brown (2001) states that error refers to those idiosyncrasies of 
system within which a learner is operating at the time. While, Dulay and Burt (1974) say that error is noticeable deviation from the adult grammar of a native speaker reflecting the inter-language competence of the learner. While, mistake on the other hand refers to a performance error that is either a random guess or a slip in that it is a failure to utilize a known system correctly. Therefore, a speaker who makes a mistake can easily correct the ill formed utterance he produces, as it is only the result of a slip of tongue or a failure in pronouncing or using certain words. Unlike the speaker who commits mistake which can be corrected by the speaker himself, a speaker who makes errors in using a language cannot correct them without other inputs in concern to the errors he makes because the ill formed utterance emerge as the result of this imperfect knowledge on the linguistic system of the language he used.

\section{Error Analysis}

Error analysis is a type of linguistic analysis that focuses on the errors learners make. It consists of a comparison between the errors made in the Target Language (TL) and that TL itself. According to Brown (1994:206) that errors can be observed, analyzed and classified to reveal something of the system operating within the learner, led to rush forward of the study of the learner's errors.

Error analysis has played an important role in creating a different perspective. Error should be regarded as normal and inevitable features of target language learning. The development pattern of error in an individual learner should be taken as evidence not of failure and weakness but as important not least for it representation of the role of the learner, who is seen no longer as a more passive recipient of the target language input, but as playing an active role in the learning process.

According to the writer, the role of error analysis is very important. An error analysis might not be avoided in order to have better understanding toward the field of this investigation is laid. Being aware of this, the writer suggested that an English lecturer should know error analysis in details.

\section{a. Interference}

A sentence in the target language is interfered by the mother tongue. This error refers to the different rule of the languages. As known that the second (L2) is the language used by the learners after mastering the first language (L1).In such a condition, mastering of $\mathrm{L} 1$ is better the $\mathrm{L} 2$ Therefore, the possibility of mastering the first language is higher of L2 influence either in Phonology, morphology, syntax, or lexicon.

\section{b. Intra-Language}

The concept of inter-language (LI) might be better understand if it thought of as a continuum between the first language (LI) and second language (L2) along which all learners traverse. According to Slinker (1974:60), one of the major issues for which any description of inter-language (LI) must account is the phenomenon of fossilization. Corder (1974) also suggests that once language learner's inter-language grammar is sufficiently developed to enable the learner to communicate adequately for his or her purpose.

\section{c. Bilingual}

The term bilingualism refers to the use of two languages. Sociolinguistics, in general, bilingualism is meant as the use of two languages by a speaker in his or her interaction with others inter-changeably (Mackey and fishman,1975:73). To be able to use two languages, people certain have to masters both of them. Firstly, they have to master their first language (L1) and secondly their second language (L2) . Those who are able to the two languages are called bilingual.

\section{Classification of Errors}

Dulay (1982:154-162) categorizes errors into four types, namely omission, addition, misformation, and misordering .

\section{a. Omission}

This kind of errors, which are characterized by the absence of an item that must be appear in a well-formed utterance Dulay (1982:156).

\section{b. Addition}

In omission category errors, certain item disappears. In contrast, certain item appears in learners' sentences production. As in "He cans swim well". The boys works everyday" and so on. The appearance of /s/ in "can" and in "work" is not needed. That's two examples above are ill-formed sentences. Dulay (1982:34) termed such errors, as addition errors that are presence 
if item must not appear in a well-formed utterance.

In this further explanation, Dulay (1982:35) classifies addition errors into three types: double marking regularization, and simple addition. Firstly, double marking errors are characterized by the presence of two or more similar items in an utterance or in a sentence. For example, "He does not goes to school". The second category of addition error is regularization. This error refers to the application of language rules without considering some exception of the rules. For example, my book is baderthan your book. The linguistic rule of degrees of comparison states that "er" is added to aone-syllable adjective to form comparative degree. But this rule has an exception towards certain adjectives such a good, bad, far, little, etc.

\section{c. Misformation}

Misformation errors are characterized by the use of wrong form of the morpheme of structure Dulay (1982:158). He also divides misformation errors into three types: regularization, archi forms, and alternating forms.

Regularization errors which fall under the category of misformation are the errors which regular maker is used in place of an irregular position. Let us take an example:"The young couple have three child". In the term of part of speech, in this case, "noun", is distinguished between singular and plural noun especially for countable nouns. The plural nouns, in common rule are characterize by the adding of suffix "s" or "es". However, there are some nouns, which do not follow the regular rule of pluralization. Those words are sometimes categorized into exception words and change irregularly. The sentence "The young couple have three child", the speaker regularized the rule of pluralization is termed achieve form errors, which refer to the errors committed bu language learners by selecting one number of a class of form to represent others in all context.

The third sub-type of misformation is termed alternating-forms, which indicates that language learners alternate structureform freely.

\section{d. Misordering Error}

Language learners sometimes make errors on the placement of morphemes or group of morphemes in the sentence they produce. This kind of errors, according to Dulay (1982:40), is termed as disordering error.

\section{B. Definition of Narrative}

The students are learning many texts. One of texts is narrative text. It is related to the experience or story of past time. Marahamin (1999:96) defined "Narrative is a story based on the plot, and plot consists of event, person, and conflict".

\section{Notions of narrative text}

As Semi (2003:29) in Hasani (2005:22) stated that narrative is conversation or writing with the purpose tells about action or human experience based on the development of time.Keraf (1991:136) stated that "Narrative as a story tells or describes an action in the past time clearly, so narrative is tried to answer the question: what happened". Narrative as a story, so it is should have the element that can make the story more interesting to the reader such as a conflict and conclusion of the story.

\section{The Characteristic of Narrative}

According to explanation of narrative, we can conclude the characteristic of narrative, are 1 ) it is a story or it is usually human experience; 2) it has a conflict and solving problem, 3) systematic. Semi in Hasani (2005:27) states that, the other characteristic of narrative, it has aesthetics; it should have imagery to increase the reader's interest.

\section{Kinds of Narrative Text}

Keraf (1991: 136) defines those kinds of narrative:

\section{a. Expository Narrative}

Expository narrative is usually tells the information about the event based on factual data. It also tells about the steps of the event to the reader. The object in expository narrative is beginning the first until the end; it means that the writer tells the story from the first until the end. The purpose of narrative is to make the reader's knowledge about object of story is deeply.

\section{b. Suggestive Narrative}

Different from expository narrative, suggestive narrative can be unsuitable with the factual data, because it emphasizes the suggestive sense. So, the purpose of suggestive narrative is to increase the reader's imagination. Hasani (2005:290) Says "narrative suggestive is narrative that tried to give a certain purpose tell an explicit 
message to readers or listener so they fell that they are involved in the story".

Referring to the explanation above, the narrative is tells the story based on the human experience in the first until the end to give a certain purpose tell an explicit message to readers about object of story deeply.

\section{Composition and Plan for Writing Narrative}

Writing strategies are deliberate, focused ways of thinking about writing. A writing strategy can take many forms. (http://www.gse.buffalo.edu/org/writing strategies/index.html)

From the definition above, writing strategies are some technique it can be a formal plan a teacher wants students to follow to write a book report, or it can be something as simple as track to remember how a word is spelled.

Preparing a writing plan for a specific text type from this they can put a plan for writing a descriptive report in the future, for example: (Department of education and early childhood development, 2006)

a. Title of the narrative

b. Setting of the narrative

c. The main characters of the narrative and how they develop

d. The main background of the narrative

e. The events that lead up to the problem or challenge (the complication)

f. The events that lead up to the problem/challenge being solved (the resolution)

g. The ending (the conclusion)

Students use a range of strategies including the following:

a. Students describe their action plan for writing, and the actions they will use to achieve their goals or purpose for writing.

b. Students use idea generation and collation strategies, orientation strategies, and idea organization strategies, for example, brainstorming and semantic mapping (including computer and graphic organizer in planning and collecting knowledge for writing different text types) and strategies for narrative or expanding a topic prior to drafting.

c. Students use drafting strategies in which students; 1) use the idea and perspectives generated to write a first draft; 2) elaborate initial ideas and identify subordinate ideas; and 3) focus on developing ideas, details and organizing them.

d. Students use revising strategies such as rereading the draft to check that there is consistency of learning and main ideas, language use and style, and modify the draft accordingly.

e. The students use editing strategies to check the use of spelling, punctuation, grammar, and capitalization; students use several resources such as a dictionary, computer and style guides.

f. Students use publishing strategies such as;

1) Selecting a format for publication appropriate for the audience for example a letter, a poster, an essay, a report); and

2) Using technology to support the publishing process.

From the above explanation, we know that by knowing the plan of writing, the students' can be good written if their use strategies in make composing narrative writing.

\section{Simple Past Tense}

1. Definition of Simple Past Tense

English simple past tenses is one of English tenses form that used by students to write simple paragraph that possible for students to appearing their story or an event that happened in the past time in correct way. Martin (2005:8) states that, English past tense is the simplest tenses to talk about a single complete in the past event.

\section{Formulas and Example of Simple Past Tense}

Murphy (1990: 13) defines those formulas and examples of simple past:

Nominal form:

You/they/we + to be (were)

l/he/she/it + to be (was)

Verbal form:

I /You/they/we/he/she/it + V2

Example:

1. I was here last night

2. They were happy last week

3. I went last week

Simple past tense in interrogative sentences:

If we are going to make an interrogative sentences, To be (was/were)in nominal form put on the front of subject, then for verbal form add with Did that place on the front of subject.

Example:

1. Was I broke the glass? 
2. Werethey noisy in the room last night?

3. Did we move the chair?

Simple past tense in negative sentences:

If we are going to make negative sentences, we need to add -notbehind to be (was/were)on nominal form.

While in verbal form add didbehind itand follow bynot.

Example:

1. They were not busy when my father came

2. She was not here last month

3. You did not (didn't) kick the table Time Signal:

Yesterday

yesterday morning

Last Monday

an hour ago

Two days ago

in 1980

Last night

the other day

Last year

everyday last year

\section{RESEARCH METHODOLOGY}

\section{A. Research Design}

This study was descriptive qualitative. Qualitative research is an approach called as an investigative approach because the researcher usually collects the data by direct contact and does the interaction with people in a research place (McMillan and Schumacher, 2003, in Syamsuddin and Damaianti S. Vismaia, 2007). By qualitative approach, the researcher would describe and analyze every individual in their life and their thinking.

The researcher used this method to examine the events or phenomena of students, especially to find out "errors analysis using simple past tense in writing a narrative text". Sugiono (2005:60, in Syamsuddin and Damaianti S. Vismaia, 2007) states that the qualitative research is a research that is used to describe and analyze phenomena, event, social activity, attitude, belief, perception and people' thinking either in individual or in a group.

\section{B. Time and Participants of the Study}

This study was held at the English Department of STKIP Paracendekia NW Sumbawa in academic year 2014/2015. The participants were 12 the second semester students of English Education Department of STKIP Paracendekia NW Sumbawa in academic year 2014/2015.

\section{Research Instrument \\ 1. Writing test}

The writing test is to write a narrative text by using simple past tense. The students were asked to write in completed narrative text using by appropriate simple past tense.

\section{Observation}

In this observation the writer as an observer, just only observed and not involved in the teaching process.

\section{Technique of Data Collection}

The data needed is the research consisted of students' errors in using English simple past tense collected by using test. In administrating the test, the researcher used some steps: First, giving the explanation of test was going to be given. Second, each student was given the test and asked them to answer the test properly. Third, after finishing doing the test on the time provided, their answer sheets were collected and for the last time, the students' answers were going to be evaluated.

\section{E. Technique of Data Analysis}

This research used a descriptive analysis, it means that the data collected were analyzed by using a descriptive technique. The data were analyzed as follows:

1. Categorize kinds' of error made byall of the students.

2. Tabulate percentage of students' error made by all of the students.

3. Predict causes of errors of using English simple past tense.

4. Evaluate the causes of error made by the students in using the English simple past tense

\section{RESEARCH FINDINGS AND DISCUSSION}

\section{A. Finding of Students' Errors}

Considering the result of data, the researcher found the number of errors by the students were $9(75 \%)$ on misformation, the number of errors by the students were 7 (58.33\%) on omission and the number of errors by the students were $6(50 \%)$ on addition. As it was stated previously, the maximum errors were made by the students from the test delivered was 14 errors on formation, and minimum was 9 errors on omission and addition. 
Table 1. Kinds of errors' committed by the students

\begin{tabular}{clccc}
\hline No & $\begin{array}{c}\text { Kinds of errors } \\
\text { committed }\end{array}$ & \multicolumn{2}{c}{ Number \& Percentage } & Committ \\
\cline { 3 - 4 } & Number & Percentage & & students \\
\hline 1 & Addition & 9 & $50 \%$ & 6 \\
2 & Omission & 9 & $58.33 \%$ & 7 \\
3 & Misformation & 14 & $75 \%$ & 9 \\
\hline
\end{tabular}

\section{B. Kinds of Error}

1. Addition Error

The data of the study was obtained from the students' errors in using simple past tense in writing narrative text. For example, "we are was there last month", "we were went to school", "we saw many peoples there" are including to addition errors.

Table 2. Students' errors in Addition

\begin{tabular}{cccl}
\hline No & Code & N.Errors & Errors \\
\hline 1 & A & 3 & $\begin{array}{c}\text { - (1) We sangs, (2)we were direct prepares, and (3)we were } \\
\text { direct }\end{array}$ \\
2 & B & 1 & - I also tries another funny enthrall \\
3 & C & 1 & - we saw many peoples there \\
4 & F & 1 & - After dinner we were slept at 01.00. Pm. \\
5 & G & 2 & $\begin{array}{l}\text { - (1) That's my experience is very happy and scared. } \\
\text { - (2) The experience is can't I forgot, forever }\end{array}$ \\
6 & J & 1 & - I had planned to follow my uncle went to the garden. \\
\hline Total & 6 & 9 &
\end{tabular}

\section{Omission Error}

The examples of omission errors such as, "we there last month", "they very happy", "we discuss about the topic". Those examples include to omission because there are absence of certain item.

Table 3. Students' errors in Omission

\begin{tabular}{|c|c|c|c|}
\hline No & Code & N.Errors & Errors \\
\hline 1 & A & 2 & $\begin{array}{l}\text { - (1) we felt happy visit the labu pade beach. } \\
\text { - (2) we visit the labu pade beach again. }\end{array}$ \\
\hline 2 & B & 1 & \\
\hline 3 & $\mathrm{D}$ & 1 & - I prepare some clothes for I wore in my village. \\
\hline 4 & $E$ & 1 & - Las month I went to labu pade with my friends. \\
\hline 5 & G & 2 & $\begin{array}{l}\text { - The beach very beautiful and good. } \\
\text { - (1) Lat month, our class went to labu pade for picnic. }\end{array}$ \\
\hline 6 & $\mathrm{H}$ & 1 & - (2) Las week I went to the market with my mom. \\
\hline 7 & $\mathrm{~K}$ & 1 & $\begin{array}{l}\text { - Although the wheater very hot. } \\
\text { - After we arrive in there. }\end{array}$ \\
\hline Total & 7 & 9 & \\
\hline
\end{tabular}

\section{Misformation Error}

The examples of misformation errors such as "we was there last month", "we was glad visit that place", "we celebrate with drinking coconut ice" those examples are include to misformation error which not accepted in grammatical rule because of the wrong placement or form.

Table 4. Students' errors in Misformation

\begin{tabular}{cccc}
\hline No & Code & N.Errors & Errors \\
\hline 1 & A & 2 & $-(1)$ We go there early morning. (2)Finally, we in kelungkung \\
2 & B & 2 & - (1)We is very tired. (2) me took a rest around there \\
3 & C & 1 & - Semongkat is one place in Sumbawa is beautiful place. \\
\hline
\end{tabular}




\begin{tabular}{|c|c|c|c|}
\hline 4 & $\mathrm{~F}$ & 1 & - me made a castil from sand. \\
\hline 5 & $\mathrm{H}$ & 2 & $\begin{array}{l}\text { - (1) me and my friend swam, } \\
\text { - (2) me and my friends went holiday to labu padi }\end{array}$ \\
\hline 6 & I & 1 & - After that, me prepared to go home with the same bus. \\
\hline 7 & $\mathrm{~J}$ & 1 & - When I will to climb banana boat be lost my money. \\
\hline 8 & $\mathrm{~K}$ & 1 & - First, the road passes away kerato then sering. \\
\hline 9 & $\mathrm{~L}$ & 1 & - If didn't we Pedang very strong, so we push the cycle until up. \\
\hline Total & 9 & 14 & \\
\hline
\end{tabular}

\section{The Causal Factors of Error}

The first factor was inter-lingual factor in using simple past tense. It was known that in simple past tense, the choose of the word form should consider. That happen because there are so many form of word or V2 still as the based problem when students' write something in past.

The second factor of the students' errors caused by intra-lingual factor. It concerned more on the complexity system of English in using simple past tense.

\section{a. Adverb Interference}

This cause appears when adverb patterns of native language (indonesian) are transferred into foreign language (English).

Example; at there we tried many games should we tried many games there, at there replace to there.

Table 5. Students' errors in adverb interference

\begin{tabular}{cccc}
\hline No & Code & N.Errors & Errors \\
\hline 1 & A & 1 & - After we arrive in there \\
\hline Total & 1 & 1 & \\
\hline
\end{tabular}

\section{b. Copulative Verb Interference}

This cause occurs because the foreign language is very different from the native language in accordance with copulative verb. It seems that learners tend to miss copulative verbs (be verbs) in the sentences.

Example;she very lonely should she look very lonely.

Table 6.Students' errors in copulative verb interference

\begin{tabular}{cccc}
\hline No & Code & N.Errors & Errors \\
\hline 1 & $\mathrm{E}$ & 1 & - Although the weather very hot. \\
2 & $\mathrm{G}$ & 1 & - Me and all of my friends very happy with that holiday. \\
\hline Total & 2 & 2 & \\
\hline
\end{tabular}

\section{c. Word Order Interference}

This cause emerges when the composition of word order, particularly noun phrase and adjectival phrase, or the foreign language is different from the native language. In the native language modifier word should be placed after the modified word, but on the contrary in the foreign language modifier word should be put before the modified word.

Example; Store handicraft should become handicraft store.

Table 7.Students' errors in word order interference

\begin{tabular}{cccc}
\hline No & Code & N.Errors & Errors \\
\hline 1 & C & 1 & - Do you know beach Saliper ate? \\
\hline Total & 1 & 1 & \\
\hline
\end{tabular}

d. Tense form Interference.

This cause emerges when learners tend to use their verb after subject without pay attention to thestructure of grammatical rules.

Example; He brake the glass should he broke the glass 
Table 8. Students' errors in tense forminterference

\begin{tabular}{cccc}
\hline No & Code & N.Errors & Errors \\
\hline 1 & $\mathrm{E}$ & 1 & - We happy went to Semongkat. \\
2 & $\mathrm{~F}$ & 1 & - we training basket ball. \\
\hline Total & 2 & 2 & \\
\hline
\end{tabular}

e. Overgeneralization

This cause emerges when learners tend to use their common senses and come to generalization of certain sets of grammatical rules. $\mathrm{Pm}$

Example; After dinner we were slept at 01.00. pm should After dinner we were sleep at 01.00.

Table 8. Students' errors in overgeneralization

\begin{tabular}{cccc}
\hline No & Code & N.Errors & Errors \\
\hline 1 & $\mathrm{~A}$ & 1 & - I can went there once again. \\
\hline Total & 1 & 1 & \\
\hline
\end{tabular}

\section{f. Ignorance of Rule Restriction}

This cause appears when it is closely related to the generalization of deviant structures which learners fail to observe the restriction of existing structure, that is, the application of rules to context where they did not apply.

Example; I hoped, we visit the Kencana beach again should become $\underline{\text { I hopes. }}$

Table 9. Students' errors in ignorance of rule restriction

\begin{tabular}{cccc}
\hline No & Code & N.Errors & Errors \\
\hline 1 & $\mathrm{D}$ & 1 & - We are all plants will went to there again someday. \\
\hline Total & 1 & 2 & \\
\hline
\end{tabular}

\section{g. Incomplete Application of Rules}

This cause happens when learners do not apply all the rules they have learned, which is due to incomplete learning. In other words, they do not completely master the rules and their application, and therefore they do not implement those rules in accordance with the circumstances. Example; the river very beautiful should the river is very beautiful.

Table 10. Students' errors in incomplete application of rules

\begin{tabular}{cccc}
\hline No & Code & N.Errors & Errors \\
\hline 1 & $\mathrm{~F}$ & 1 & - Finally, we in kelungkung \\
\hline Total & 1 & 1 & \\
\hline
\end{tabular}

\section{CONCLUSION AND SUGGESTION}

A. Conclusion

1. Based onthe data analyzed above. The researcher found out that the students' errors are classified into addition, omission, and misformation, those were; errors by the students was $9(75 \%)$ in formation, $7(58.33 \%)$ in omission and 6 $(50 \%)$ in addition.

2. Knowing the fact that based on discussion. The researcher concluded that there were six kinds of causal factors errors. Those were; adverb interference, copulative verb interference, word order interference, tense forminterference, errors in over generalization, ignorance of rule restriction, and incomplete application of rules.

It can be concluded that the second semester students of English Education Department of STKIP Paracendekia NW Sumbawa in academic year 2014/2015 still found some difficulties on the using simple past tense in writing a narrative text.

\section{B. Suggestion}

The researcher found that the second semester students of English Education Department of STKIP Paracendekia NW Sumbawa in academic year 2014/2015 still made some errors in using the formulas of simple past tense. The researcher would like to 
offer some suggestion both to students' and the lecturers of English.

1. The language system underlying simple past tense is complex. So, it is suggested to the lecturer to create good strategy in teaching the formulas of simple past tense, by giving the students' more practice.

2. It is suggested to the students to remember the used of V2 and practice using simple past tense in spoken or written form as productive skill.

\section{REFERENCES}

Brown, D.B. (1994). Principles of Language Learning and Teaching. Third Edition. New Jersey: Prentice Hall Regents.

Brown, H, D. 2001. Teaching by Principles An Interactive Approach to Language Pedagogy. New York: San Francisco State University press.

Corder, S. P. (1974). Error Analysis. In J. P. B. Allen and S. Pit Corder (eds.) Techniques in Applied Linguistics (The Edinburgh Course in Applied Linguistics:3), London: Oxford University Press (Language and Language Learning), pp. 122-154.

Dulay, H., Burt, M., \& Krashen, S. 1982. LanguageTwo. New York: Oxford University Press.

Harmer, J.(2001). The practice English language teaching. Essex, UK; Pearson education.

Hasani. (2005). Ihwal Menulis. Untirta Press

http://www.gse.buffalo.edu/org/writingstrategies/i ndex.html. (Downloaded 10 August 2015)

Ismail, Marahamin. 1999. Menulis secara populer. Jakarta: Pustaka jaya

Keraf, Gorys. 1991. Argumentasi dan Narasi. Jakarta: PT. Gramedia

Langan, Jhon. 2001. College Writing Skills with Reading $\left(5^{\text {th }} \mathrm{Ed}\right)$. New York: McGraw-Hills Companies.

Mackey , W.F. (1975) . Language Teaching Analysis. London: Longman.
Martin, H. (2005). Advanced Grammar in Used. UK. Cambridge University Press.

Murphy. (1990). Essential grammar in use. UK. Cambridge University Press.

Richards J.C. (ed. 1974). Error analysis: Perspectives on second language acquisition. London: Group limited, Longman.

Richards J.C. (ed. 1992). Error analysis: Perspectives on second language acquisition. London: Group limited, Longman.

Selinker, L. (1974). Interlanguage. In Richards, J. (Ed.). Error analysis: Perspectives on Second Language Acquisition. 31-54. Essex: Longman.

Syamsuddin by Damaianti S Vismaia. 2007. Metode Penelitian pendidikan Bahasa. Bandung : Pt Remaja Rosdakarya Offset 